\title{
Information Technology and Cost Efficiency in Malaysian Banking Industry
}

\author{
MOHD. ZAINI ABD. KARIM \\ ABDUL RAHIM ANUAR \\ SHAZIDA JAN MOHD. KHAN \\ Faculty of Economics \\ Universiti Utara Malaysia
}

\begin{abstract}
It is argued that information technology can increase cost efficiency of banks by offering opportunities to substitute across inputs into production - for example, to substitute computer technology and information networks for labor. Hence, the transition to a knowledge-based financial sector would lead to banks becoming more competitive, more cost effective and better able in managing risks. As such, those banks that failed to make this transition are less able to compete as they lack the capability to innovate and face higher delivery costs. The main objectives of this paper are to determine the impact of IT on banking efficiency and its economies of scale using a sample of Malaysian banks. To achieve these objectives, stochastic cost frontier method is employed to estimate bank efficiency and panel data approach were used to examine the impact of IT on bank efficiency. The results indicate that the impact of IT on bank efficiency increases with increase in bank size, hence further supporting the process of bank mergers that are currently undertaken in the Malaysian banking industry.
\end{abstract}

\begin{abstract}
ABSTRAK
Teknologi maklumat dikatakan mampu meningkatkan kecekapan kos bank-bank dengan menyediakan peluang untuk penggantian input dalam pengeluaran - sebagai contoh, penggantian buruh dengan teknologi komputer dan rangkaian maklumat. Oleh itu, transisi kepada sektor kewangan yang berasaskan maklumat akan menjadikan bank-bank lebih cekap, keberkesanan kos dan mampu untuk mengurus risiko. Kegagalan untuk beralih ke arah teknologi maklumat akan menyebabkan bank-bank kehilangan daya saing disebabkan ketidakmampuan untuk menghasilkan produk-produk yang inovatif di samping peningkatan dalam kos pengeluaran. Objektif utama kertas ini ialah untuk menentukan kesan teknologi maklumat ke atas kecekapan dan skala ekonomi dengan menggunakan sample bank-bank di Malaysia. Bagi mencapai objektif ini, kaedah "stochastic cost frontier" digunakan untuk menganggarkan kecekapan bank dan pendekatan panel data digunakan untuk melihat kesan teknologi maklumat ke atas kecekapan tersebut. Hasil kajian menunjukkan kesan teknologi maklumat ke atas kecekapan bank meningkat dengan peningkatan dalam saiz bank. Dapatan ini menyokong lagi proses penggabungan bank-bank yang sedang dijalankan dalam industri perbankan Malaysia
\end{abstract}

\section{INTRODUCTION}

In this era of information revolution, Information Technology (IT) has been recognized as a power- ful tool to promote economic development. As Malaysia transforms to a knowledge-based economy, the application of IT will represent an important enabling tool in this transformation 
process through the enhancement of productivity and quality of the workforce. In most of the service industries - telecommunications, banking, insurance, retailing and marketing, health, transport, and the leisure and entertainment industries, technology will be the main driver of change. All these changes will have beneficial social impacts, through improving the range of services available, and the convenience, speed and efficiency of delivery of services.

In the world of banking, the developments in information technology have had an enormous effect in the development of more flexible payment methods and more user-friendly banking services. Investment in new technology will help to enhance the effectiveness and efficiency of banks. It is argued that information technology can increase cost efficiency of banks by offering opportunities to substitute across inputs into production - for example, to substitute computer technology and information networks for labor. Hence, the transition to a knowledge-based financial sector would lead to banks becoming more competitive, more cost effective and better able in managing risks. In other words, a knowledgebased financial sector uses both IT and skilled workers that have the ability to make use of IT towards creating innovative financial products which can lead to banks becoming more efficient in dealing with Business to Business (B2B) and Business to Customer (B2C).

However, empirically, the relationship between investment in Information Technology (IT) and bank productivity has been a vexing, to a large extent, unresolved issue despite the above straightforward argument. Existing empirical studies both at the industry level and at the firm level have not reached consensus in their conclusions that the higher levels of spending in IT by businesses improved their productivity, leading to the term "IT Productivity Paradox".

The objective of this paper is to discuss the development of IT in the Malaysian banking industry and to analyze empirically the impact of IT on efficiency using firm-level data on Malaysian banks. In doing so, we can also determine whether the use of IT has any effects on the economies of scale of the banks. Our study differs from previous work on the relationship between IT and bank productivity by examining the impact of IT on the cost efficiency of banks whereby the cost efficiency scores were estimated using a stochastic cost frontier function.

The rest of the paper is organized as follows. Section 2 reviews the logic and evidence on the relationship between IT and productivity. Section 3 discusses the development of IT in the Malaysian banking industry. Section 4 describes the methodology used in estimating bank efficiency and the effects of IT on bank efficiency. Section 5 discusses the data used and the empirical results. Section 6 concludes the paper.

\section{IT AND PRODUCTIVITY: LOGIC AND EMPIRICAL EVIDENCE}

People have speculated about the effects of computers on economic productivity since the first time computers were used in business. Based on the simple observation that computers can do certain task much faster and less expensively than individuals can, it is natural to assume that replacing selected employees of a business with computers will greatly increase the speed and reduce the cost of certain business activities.

This straightforward and compelling logic led many computer vendors in the early years of the computer industry to emphasize productivity improvements as one of the most important reasons for buying computers, and it led many computer buyers to expect significant productivity improvements as a result of their purchases (Berndt \& Malone, 1995). In many individual cases, dramatic productivity improvements were obvious, and for many years, both buyers and sellers generally assumed that such improvements were common. In the late 1980's, however, a stream of research began to appear that questioned this basic assumption. An increasing number of careful economic and other studies found no evidence of productivity improvement from the use of IT, and in some studies, IT even appeared to be associated with decreases in productivity or subnormal investment returns (Loveman, 1988; Morrison \& Berndt, 1990). This surprising phenomenon came to be called the "IT productivity 
paradox". Companies were spending more and more each year on massive amounts of information technology, and yet, paradoxically, careful economic studies found little or no benefits from these investments. However, of late, researchers working with firm level data have found significant contributions from IT towards productivity (for example, Lichtenberg, 1995; Brynjolfsson \& Hitt, 1996).

The effects of IT on financial services productivity too are not conclusive. In their study on the productivity of banking services in Canada, (Parsons, Gottlieb \& Denny, 1990) estimated a production function for the banking sector and found that overall, the impact of IT on multifactor productivity was quite low between 1974 and 1987. They speculated that IT has positioned the industry for greater growth in the future. Similarly, Prasad \& Harker (1997) estimated a production function for the retail banking services in United States and found that additional investment in IT capital may have no real benefits. They may be more of a strategic necessity to stay even with the competition. However, there are substantially high returns to increase in investment in IT labor suggesting that retail banks should not only invest in IT capital but also in training of IT personnel to receive greater overall IT benefits.

On the other hand, Harris \& Katz (1989) looked at data on the insurance industry from the Life Office Management Association Information Processing Database. They found a positive relationship between IT expense ratios and various performance ratios, although at times the relationship was quite weak. Based on the previous studies on the relationship between IT and productivity, we can make several conclusions; first, there is mixed evidence on whether investment in IT improves productivity. Second, several reasons that can explain this productivity paradox aside from measurement and data issues. One reason is delayed payoffs from a very long period of investment and evolutionary learning, a symptom of an economy in transition, in this case to the "information era". For instance David (1989) makes an analogy to the electrification of factories at the turn of the century. Major productivity gains did not occur for 20 years, when new factories were designed and built to take advantage of electricity's flexibility which enabled machines to be located based on work-flow efficiency, instead of proximity to waterwheels, steam engines and power-transmitting shafts and rods; another reason to explain the productivity paradox is lack of technical expertise impedes the diffusion of technologies. As the "process engineers" of the organization, IT labor is crucial in the design, control, and execution of service delivery in banks. Thus, a key driver of efficiency and effectiveness in the industry is the management of IT labor force and procurement process; the third reason is IT may be beneficial to individual firms, but unproductive from the standpoint of the industry as a whole or the economy as a whole, i.e. IT rearranges the shares of the pie without making it any bigger. For instance, IT may be used disproportionately for market research and marketing, activities which can be very beneficial to the firm while adding nothing to total output. Firms with inadequate IT budgets would lose market share and profits to high IT spenders. The recent popularity of "strategic information systems" designed to take profit from competitors rather than to lower costs may be illustrative of this thinking. On the other hand, the original impetus for much of the spending on electronic data processing (EDP) was administrative cost reduction. This is still the principal justification used in many firms.

\section{Developments of IT in the Malaysian Banking Industry}

The business of banking today has become more complex due to sophisticated consumer demands and rapid advances in ICTs. Manual operations have been taken over by ICTs as these operations are no longer capable of handling the increasing volume of transactions. Banking institutions have started investing heavily in information technology to enhance their services to remain competitive and to provide new banking products in order to gain market share. In line with global trends, banking business in Malaysia too has been undergoing tremendous changes since achieving independence in 1957. The first step in the evolutionary process was the gradual deregulation of the financial sector, which commenced in the 1970's. Then, in the 1980's the introduction of 
Automated Teller Machines (ATM's) can be considered as the first and most visible piece of evidence of the emerging electronic banking in Malaysia. This was then followed by the introduction of telebanking and later on PC-banking in the 1990's. The next imminent step in this evolutionary process inevitably appears to be Internet-banking (Guru et al., 2000). However the development of IT within the sector might be hampered by the shortage of qualified and experienced IT personnel due to skilled personnel moving to other industries.

Table 1

IT Capital and Operating Expenditure of the Banking Industry

\begin{tabular}{|lcccc|}
\hline & \multicolumn{2}{c}{ Capital Expenditure } & \multicolumn{2}{c|}{ Operating Expenditure } \\
\hline & Avg 1992-94 & Avg 1995-97 & Avg 1992-94 & Avg 1995-97 \\
Hardware & $66 \%$ & $57 \%$ & - & - \\
Software & $24 \%$ & $30 \%$ & - & - \\
Data Communication & $5 \%$ & $9 \%$ & $5 \%$ & $8 \%$ \\
Maintenance & - & - & $30 \%$ & $35 \%$ \\
Staff Cost & - & - & $27 \%$ & $28 \%$ \\
Lease Rental & - & - & $18 \%$ & $10 \%$ \\
Others & $5 \%$ & $4 \%$ & $20 \%$ & $19 \%$ \\
& & & & \\
\hline
\end{tabular}

Source: Bank Negara Malaysia. Annual Report

According to the Annual Report of Bank Negara Malaysia (1995), skilled IT personnel are scarce resources in the banking industry as only 40 percent of full time technical staff has more than five years working experience. As of the end of June 1995, the industry's 2,485 technical staff accounted for 3.6 percent of the industry's total employees. On the whole, the banking industry had a total of 1,996 personnel employed in IT operations of which 57 per cent had less than five years of experience. In terms of IT training, the commercial banks spent an average of 10 percent of total staff training expenditure on IT staff training. Responding to this demand, the education system, in particular institutions of higher learning (IHLs), has a very important role to play in creating $\mathrm{K}$-workers in general and the banking industry in particular. This requires both the government agencies concerned and the IHLs to continuously improve and upgrade their academic standards so as to remain relevant and competitive.

IT capital investments in the banking industry had started to take place since 1990 . As can be seen in Table 1, IT capital expenditure mainly focuses on hardware and followed by software. In contrast, maintenance expenditure dominates IT operations. Table 2 shows main areas of computerization of commercial banks. Almost 75 percent of their operations is in main four functional areas (deposit handlings, financial management, loans products and electronic 
delivery channels (including ATMs) have been computerized. In operations of branches, local area network (LAN) is being used widely where 36.7 percent of the industry's units of LAN personal computers belonged to the large banks (Bank Negara Malaysia, 1995). The IT investment structure, to an extent, reflects the type of Kworkers needed in the banking sector.

Table 2

Main Areas of Computerization of Commercial Banks

\begin{tabular}{|c|c|c|c|c|c|c|c|c|}
\hline \multirow[b]{2}{*}{$\begin{array}{l}\text { Functional } \\
\text { Areas }\end{array}$} & \multicolumn{6}{|c|}{ Fully Operational Systems } & \multicolumn{2}{|c|}{ Extent $^{1}$} \\
\hline & All & Large & Medium & Small & Foreign & Domestic & $\begin{array}{c}50- \\
<75 \%\end{array}$ & $\begin{array}{c}75- \\
100 \%\end{array}$ \\
\hline Deposit Handling & 37 & 4 & 8 & 25 & 13 & 24 & 5 & 32 \\
\hline Financial Mgt. & 28 & 4 & 7 & 17 & 10 & 18 & 5 & 21 \\
\hline Loan Products & 28 & 3 & 8 & 17 & 12 & 16 & 3 & 23 \\
\hline $\mathrm{EDC}^{2}$ & 25 & 4 & 7 & 14 & 5 & 20 & 4 & 20 \\
\hline Loan Mgt. & 24 & 3 & 6 & 15 & 12 & 12 & 3 & 20 \\
\hline Treasury $^{3}$ & 22 & 3 & 5 & 14 & 11 & 11 & 8 & 9 \\
\hline Trade Financing & 21 & 3 & 6 & 12 & 12 & 9 & 4 & 14 \\
\hline Remittances & 19 & 3 & 5 & 11 & 9 & 10 & 5 & 14 \\
\hline Loan Processing & 19 & 1 & 5 & 13 & 12 & 7 & 2 & 14 \\
\hline Corporate Fin. & 9 & 2 & 3 & 4 & 7 & 2 & 3 & 4 \\
\hline $\begin{array}{l}{ }^{1} \text { Extent of comput } \\
{ }^{2} \text { Electronic deliver } \\
{ }^{3} \text { Includes asset abi }\end{array}$ & nne & $\begin{array}{l}\text { banks } \\
\text { includ } \\
\text { ment }\end{array}$ & $\begin{array}{l}\text { ith fully } \\
\text { g ATMs } \\
\text { d risk me }\end{array}$ & operat & al syst & & & \\
\hline
\end{tabular}

Source: Bank Negara Malaysia, Annual Report

Investment in IT continues to expand rapidly at a rate of 8.4 percent per annum during the review period (1996-1998), increasing from RM3.8 billion in 1995 to RM4.5 billion in 1998 . This situation appeared to be driven by a number of fiscal incentives such as the removal of sales tax on computers and components and the granting of accelerated capital allowances for expenses on computers and other IT equipment. In terms of IT expenditure by sector, banking and finance sectors constituted the second largest share after the manufacturing sector (Government of
Malaysia, 1999). A study conducted in 1996 to assess the extent and sophistication of IT utilization by the major sectors in the economy, the banking and finance sector registered the highest percentage of companies with more than 100 personal computers (PCs), as shown in Table 3. This reflects how IT has become an important strategic tool for the banking industry. Internal networks are utilized within the banks and financial institutions to facilitate information and data exchange, particularly in the business function and accounting as well as operations and production. 
It is estimated that the banking industry will emerge as a major IT user having accounted for at least 20 percent of the nation's IT expenditure in 1995 (Bank Negara Malaysia, 1995).

Table 3

PC Penetration by Sector, 1996 (in \%)

\begin{tabular}{|c|c|c|c|c|c|}
\hline \multirow[b]{2}{*}{ Sector } & \multirow{2}{*}{$\begin{array}{c}\text { Companies } \\
\text { With PCs }\end{array}$} & \multicolumn{4}{|c|}{ Number of PCs per company } \\
\hline & & $\overline{1-10}$ & $11-50$ & $51-100$ & $>100$ \\
\hline Agriculture & 88 & 40 & 26 & 5 & 17 \\
\hline Construction & 98 & 50 & 30 & 9 & 9 \\
\hline Manufacturing & 97 & 34 & 36 & 14 & 13 \\
\hline Trade & 90 & 38 & 32 & 8 & 11 \\
\hline Health & 92 & 19 & 41 & 24 & 8 \\
\hline Transport & 100 & 46 & 36 & 7 & 11 \\
\hline Finance & 100 & 1 & 9 & 19 & 71 \\
\hline Tourism & 93 & 46 & 33 & 10 & 5 \\
\hline Education & 98 & 15 & 31 & 17 & 36 \\
\hline Business \& & & & & & \\
\hline Professional Services & 98 & 59 & 30 & 3 & 6 \\
\hline All Sectors & 93 & 37 & 33 & 10 & 13 \\
\hline
\end{tabular}

Source: Mid-Term Review of the Seventh Malaysia Plan 1996-2000

\section{METHODOLOGY AND DATA}

To analyze the relationship between IT and efficiency of banks, we will employ a two-stage estimation. In the first stage, efficiency scores for each bank and for each year in the sample were calculated by estimating a stochastic cost frontier function. The efficiency scores in this first stage estimation were then used as a dependent variable in the second stage regression.

\section{Estimation of Cost Efficiency}

To obtain the efficiency scores, we will estimate the following translog stochastic cost frontier function:

$$
\begin{aligned}
\ln C_{i t}= & \beta_{0}+\sum_{j=1}^{m} \beta_{j} \ln y_{j i t}+\sum_{k=1}^{m} \beta_{k} 1 \mathrm{n} w_{k i t} \\
& +\frac{1}{2} \sum_{j}^{n} \sum_{l}^{m} \beta_{j l} \ln y_{j} y_{l}+\frac{1}{2} \sum_{k}^{m} \sum_{p}^{m} \beta_{k p} 1 \mathrm{n} w_{k i t} 1 \mathrm{n} w_{p i t} \\
& +\frac{1}{2} \sum_{j}^{n} \sum_{k}^{m} \beta_{j k} \ln y_{j i t} 1 \mathrm{n} w_{k i t}+\beta_{q} t+u_{i t}+v_{i t}
\end{aligned}
$$

where $\ln C_{i t}$ is the natural logarithm of the total cost (discussion of what constitutes a bank's input and output will be in the next section); $\ln y_{i t}=$ the natural logarithm of the $j$ th output $(j=$ $1,2, \ldots, \mathrm{n}) ; \ln w_{k i t}$ is the natural logarithm of the $k^{\text {th }}$ 
input price $(\mathrm{k}=1,2, \ldots, \mathrm{m})$; $t$ is the year of observation; and $\mathrm{b}$ are the coefficients to be estimated. The $v_{i t} s$ are random variables associated with measurement errors in the input variable or the effect of unspecified explanatory variables in the model and the $u_{i t} \mathrm{~s}$ are non-negative random variables, associated with inefficiency of input used, given the levels of outputs and the quasi-fixed inputs as defined in the previous section.

The cost efficiency of input used for the $i$ th bank in the $t$-th year of observation, given the values of the outputs and inputs, is defined as the ratio of the stochastic frontier input use to the observed input used. The stochastic frontier input use is defined by the value of input use if the cost inefficiency effect, $u_{i t}$, is zero (i.e., the bank is fully efficient in the use of input). If a translog stochastic frontier cost function is used, the cost efficiency for firm $i$ at time $t$ is defined by equation (2),

$$
\begin{aligned}
C E_{i t}= & \frac{C_{i t}\left(y_{i t}, w_{i t} ; \beta\right) \exp \left(v_{i t}\right)}{C_{i t}\left(y_{i t}, w_{i t} ; \beta\right) \exp \left(v_{i t}+u_{i t}\right)} \\
= & \exp \left(-u_{i t}\right)
\end{aligned}
$$

where $C_{i t}\left(y_{i t}, w_{i t} ; \beta\right) \exp \left(v_{i t}\right)$ is the stochastic frontier input use of bank $i$ in year $t$ and $C_{i t}\left(y_{i t} w_{i t} ; \beta\right) \exp \left(v_{i t}+u_{i t}\right)$ is the observed input used of bank $i$ in year $t . \mathrm{CE}_{\mathrm{it}} \leq 1$. The reciprocal of this value, exp. $\left(u_{i t}\right)$, is no less than one that can be interpreted as measure of the cost inefficiency of input use.

\section{Inefficiency Equation}

We used a panel data approach to analyze the relationship between IT and bank efficiency. We estimated the following equation using both fixedeffect and random-effect model.

$$
\begin{aligned}
& I N E F F_{i t}=\alpha_{0}+\alpha_{1} I T_{i t}+\alpha_{2} S I Z E_{i t}+\alpha_{3} I T * S_{Z I Z E}+ \\
& \alpha_{4} C R_{t}+\varepsilon_{i t}
\end{aligned}
$$

INEFF is the bank inefficiency scores from the first stage stochastic cost frontier estimation.
IT is the expenditure on IT. SIZE is the size of the banks. IT*SIZE is the interaction term between the IT expenditure of the banks and bank size. $\mathrm{CR}$ is the market concentration ratio to proxy for market competitiveness. It is argued that a competitive banking market will promote the efficiency of banks since banks that are inefficient will be driven out from the market. We use the four-firm concentration ratio as a measure for market concentration. It sums up the market shares of the four largest banks in the industry. Hence, we define the four-firm concentration by $C R=\sum_{i=1}^{4}$ $s_{i}$ where $\mathrm{s}_{\mathrm{i}}=\left(100 \mathrm{q}_{\mathrm{i}} / \mathrm{Q}\right)$ is the market of firm $i . \mathrm{Q}_{\mathrm{i}}$ denote the output of firm $i, i=1,2, \ldots, \mathrm{N}$ and $\mathrm{Q}$ denote the aggregate industry-output level.

A series of estimation techniques will be employed. To control for bank-specific individual effects, the model is specified as a panel data regression with fixed effects or random effects. As in this study the sample is drawn from a population (not all Malaysian banks are included in the sample due to data unavailability), it would be appropriate to assume that individual-specific intercepts are randomly distributed across cross-sectional units. On the other hand, since this study focuses on Malaysian banks, it would also be reasonable to assume that the model is constant for the group of banks and thus the fixed-effect estimators are applicable.

The fixed-effects model assumes that slopes are common, but intercepts vary across countries.

$$
\begin{aligned}
& I N E F F_{i t}=\gamma_{i}+\gamma_{1} I T_{i t}+\gamma_{2} S I Z E_{i t}+\gamma_{3} I T * S I Z E_{i t}+ \\
& \gamma_{4} C R_{t}+\varepsilon_{i t}
\end{aligned}
$$

where $\gamma_{i}$ are the individual intercepts. The OLS estimator of the fixed-effects model is the consistent independent of whether the error and the regression are correlated or not.

The random-effects model assumes that intercepts are drawn from a common distribution, and the error term consists of two components: an error term unique to each observation and constant over time $\left(u_{i}\right)$ and an error term representing the extent to which the intercept of a given cross- 
sectional unit varies from the overall intercept $\left(\varepsilon_{i t}\right)$.

$I N E F F_{i t}=\delta_{i}+\delta_{I} I T_{i t}+\delta_{2} S I Z E_{i t}+\delta_{3} I T * S I Z E_{i t}+$ $\delta_{4} C R_{t}+u_{i t}+\varepsilon_{i t}$

where $\delta$ is the overall intercept. The FGLS estimator of the random-effects model is consistent and efficient, provided there is no correlation between the error and the regressors.

\section{Data}

The yearly data used for this study consist of ten Malaysian banks and were obtained from both balance sheets and the profit and loss accounts of the banks' annual reports from 1991-1996. Hence, altogether there were 60 observations used in this study. Only ten banks were chosen because annual reports of the other banks did not contain information on either computer related assets or expenditure. For estimation of the stochastic cost frontier function the intermediation approach is used in determining the input and output of the banks. Hence, our banks total cost will include sum expenses on wages and salaries, land buildings and equipments, and interests on deposits, while the outputs are Ringgit Malaysia (RM) amounts of commercial and industrial loans, dollar amount of other loans, dollar amounts of deposits, and ringgit amounts of securities and investments. The input price will include expenses on wages and salaries per employee (unit price of labor), expenses on land, buildings, and equipment per ringgit of assets (unit price of physical capital), and expenses on interest per ringgit of deposits (unit price of financial capital).

For the variables in the inefficiency equation (4) and (5), we use total assets as a proxy for bank size while the banks' computer related capital expenditure were used as a measure for IT expenditure. The outputs used in calculating the concentration ratio (CR) are ringgit amounts of commercial and industrial loans, ringgit amount of other loans, ringgit amounts of deposits, and ringgit amounts of securities and investments as being used in estimating cost efficiency. Table 4 presents the summary statistics for the variables used in the estimation.

Table 4

Summary Statistics for Sample Banks: 1991-1996 (in thousand RM)

\begin{tabular}{|l|c|}
\hline Variable & Mean \\
\hline Assets & $10,006,367$ \\
\hline Loans & $5,627,852$ \\
\hline Deposits & $6,431,030$ \\
\hline Securities/Investments & 834,997 \\
\hline Wages & 82,420 \\
\hline Interests Expense & 400,227 \\
\hline Non Interest Expense & 72,802 \\
\hline Computer related Expenditure & 13,393 \\
\hline Total costs & 555,452 \\
\hline
\end{tabular}




\section{EMPIRICAL RESULTS}

The mean cost inefficiencies of input use for the sample banks are presented in Table 5. The individual cost inefficiencies range from 0 percent to 110.43 percent. Thus, one bank was estimated to use about 110.43 percent more input than for a fully efficient bank with the same level of outputs. The average level of cost inefficiency for the bank studied was 5.6 percent. This indicates that on average observed cost is almost 5.6 percent more than the best practice cost. In addition, the cost inefficiencies tended to increase over the six-year period. This shows that cost inefficiencies in Malaysian banks tend to increase over the years preceding the Asian financial crisis in 1997. This supports the argument by Karim (2001) that the problem of failures of banks may have something to do with inefficiency.

Table 5

Average Cost Inefficiency of Input Use for Sample Banks

\begin{tabular}{|c|c|c|c|c|}
\hline & mean & $\min$ & $\max$ & s.d \\
\hline 1991 & 3.13 & 1.89 & 4.02 & 0.009 \\
\hline 1992 & 2.78 & 2.23 & 3.37 & 0.005 \\
\hline 1993 & 3.12 & 1.54 & 9.66 & 0.029 \\
\hline 1994 & 6.02 & 1.09 & 20.21 & 0.072 \\
\hline 1995 & 5.45 & 1.58 & 49.78 & 0.125 \\
\hline 1996 & 28.65 & 4.56 & 110.43 & 0.219 \\
\hline
\end{tabular}

We now turn our attention to analyzing the variation in the inefficiency scores. The inefficiency scores were regressed against computer related capital expenditure, bank size, the interaction term of asset size and banking market concentration ratio as in equation 2. Before turning to our results, however, it should be noted that because the dependent variable in the analysis is the inefficiency scores, the signs of all slope coefficients appearing in Table 6 are the opposite of the actual effect on efficiency.

Although the coefficient of contemporaneous IT capital expenditure is not statistically significant in both models, the results of the fixedeffect model indicate that the coefficient of lagged IT capital expenditure is statistically significant at the 10 percent significance level. In the random-effect model, the lagged IT coefficient is negatively significant in influencing bank inefficiency at the 5 percent significance level indicating that there is evidence that IT has a positive impact on the cost efficiency of banks. The issue to decide is which model, fixed effects or random effects, is more reliable. The argument is in favor of random effects if the LM statistic is large in the presence of a small Hauseman's Wald statistic (Greene, 2000). Based on the LM statistic (5.34) and the Hauseman's Wald statistic (1.32), the random effects model is more appropriate than the fixed effects model. The asset size coefficient is negative and significant at the 10 percent significance level in both models indicating that inefficiency tends to decrease with the bank's size. The coefficient of the interaction term ASSET*IT is negative and significant at the 5 percent significance level suggesting that the effect of IT 
on cost efficiency of banks increases as bank size increases. This suggest that bigger banks can have advantages in using IT than smaller banks since they are able to spread the costly investment in IT more efficiently due to economies of scale. The CR coefficient as a proxy for market competitiveness has the correct sign but is not significant in both models.

\section{Table 6}

Panel Data Analysis of Inefficiency Scores

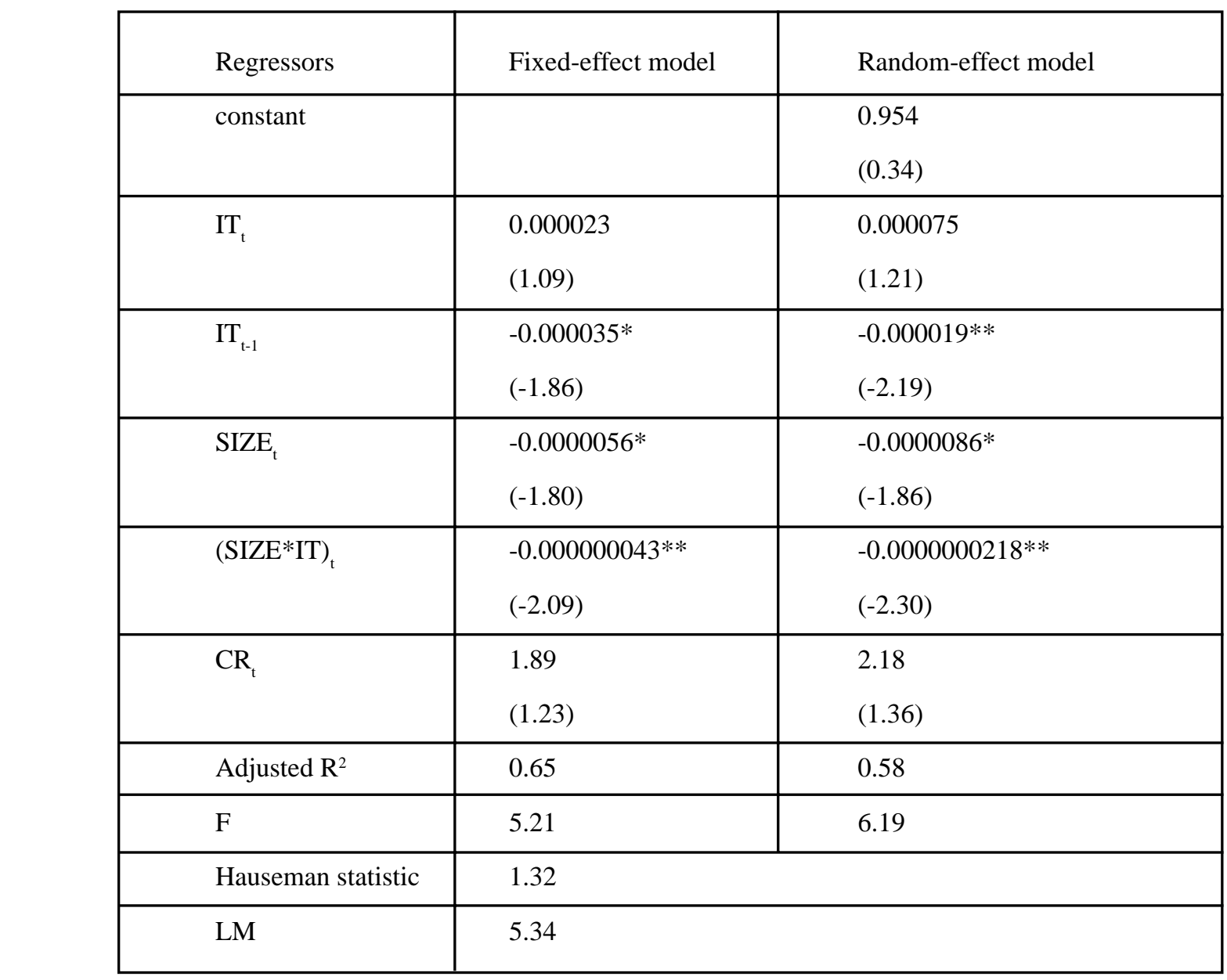

$t$-statistic are in parenthesis

* indicate statistically significant at the $10 \%$ level

** indicate statistically significant at the $5 \%$ level

\section{CONCLUSION}

Banking institutions have started investing heavily in information technology to enhance their services to remain competitive and to provide new banking products in order to gain market share. In this paper, we review the logic and evidence of the effects of IT on the productivity of banks, dis- 
cusses the development of IT in the Malaysian banking industry, and finally empirically tests the relationship of IT and cost efficiency of banks using a sample of Malaysian banks. Our findings suggest that there is evidence that IT has a positive impact on efficiency of banks. This effect tends to increase with the size of the bank. This finding provides another argument in support for bank mergers that are currently undertaken in the banking industry. The increase in bank size not only has some direct positive effect on bank cost efficiency but can also take advantage of the unavoidable proliferation of IT in banking services due to the increasing consumers demand for more efficient and user-friendly customer services, thus increasing its competitiveness to survive in the new economy and increasing globalization of the industry. However, increasing investment in IT capital itself is not sufficient unless supported by increase investment in IT labor since workers who lack IT skills will impede the diffusion of IT. This is particularly true in the case of Malaysian banking industry where skilled and competent IT personnel are relatively scarce compare to the increasing demand by the industry as stated in the Bank Negara Malaysia Report.

\section{REFERENCES}

Bank Negara Malaysia. (1995). Annual Report

Berndt, E. R., \& Malone, T. W. (1995). Information technology and the productivity paradox: getting the questions right. Economics of Innovation and New Technology, 3, 177-182

Brynjolfsson, E., \& Hitt, L. (1996). Paradox lost? Firm level evidence on the returns to information systems spending, Management Science, 42 (4), April, 541-558.

Cortada, W. J. (1998). Rise of the knowledge worker. Butterworth-Heinemann: Boston.

David, P. A. (1989). Computer and dynamo: the modern productivity paradox in a not- too-distant mirror. Center for Economic Policy Research, Stanford: California.

Government of Malaysia, (1996). Seventh Malaysia Plan 1996-2000. Prime Minister Department: Kuala Lumpur.

(1999). Mid Term Review of the Seventh Malaysia Plan 1996-2000. Prime Minister Department: Kuala Lumpur.

Greene, W. H. (2000). Econometric analysis 4th Edition. Prentice Hall: New Jersey.

Guru, B. K., Vaithilingam, S., Ismail, N., \& Prasad, R. (2000). Electronic banking in Malaysia: A note on evolution of services and consumer reactions. Journal of Internet Banking and Commerce, 5 (1), June.

Harris, S. E., \& Katz J. L. (1989). Predicting organizational performance using Information Technology managerial control ratios. in Proceedings of the Twenty-Second Hawaiian International Conference on System Science. Honolulu: Hawaii.

Karim, M. Z. A. (2001). Comparative bank efficiency across select ASEAN countries. ASEAN Economic Bulletin, 18 (3), 289304.

Lichtenberg, F. (1995). The output contributions of computer equipment and personnel: A firm level analysis. Economics of Innovation and New Technology, 3(4), 201-217.

Loveman, G. W. (1988). An assessment of the Productivity impact on Information Technologies, MIT Management in the 1990s working paper \#88-054, July.

Mid-Term Review For The Seventh Economic Plan, 1996-2000.

Morrison, C. J., \& Berndt, E. R. (1990). Assessing the productivity of information 
technology equipment in the U.S. Manufacturing Industries. NBER Working Paper \#9012, June.

Parsons, D., Gotlieb, C. C., \& Denny M. (1993). Productivity and computers in Canadian banking, The Journal of Productivity Analysis, 4, 95-113.
Prasad, B., \& Harker, P. T. (1997). Examining the contribution of information technology toward productivity and profitability in U.S. Retail Banking. Financial Institutions Center Working paper. University of Pennsylvania. 